Correspondence Mario Vaneechoutte Mario.Vaneechoutte@rug.ac.be

\section{Description of Comamonas aquatica comb. nov. and Comamonas kerstersii sp. nov. for two subgroups of Comamonas terrigena and emended description of Comamonas terrigena}

\author{
Georges Wauters, ${ }^{1}$ Thierry De Baere, ${ }^{2}$ Anne Willems, ${ }^{3}$ Enevold Falsen ${ }^{4}$ \\ and Mario Vaneechoutte ${ }^{2}$
}

\author{
${ }^{1}$ Medical Microbiology Unit, University of Louvain, Avenue Hippocrate 54, B-1200 Brussels, \\ Belgium \\ 2Department of Clinical Chemistry, Microbiology and Immunology, Blok A, Ghent University \\ Hospital, De Pintelaan 185, B-9000 Ghent, Belgium \\ ${ }^{3}$ Laboratorium voor Microbiologie, Fac. Wetenschappen, Vakgroep WE10V, Ledeganckstraat 35, \\ B-9000 Ghent, Belgium \\ ${ }^{4}$ Culture Collection of the University of Göteborg, Department of Clinical Bacteriology, \\ Guldhedsgatan 10, 6tr, S-413 46 Göteborg, Sweden
}

\begin{abstract}
Three clusters of isolates have previously been defined within the species Comamonas terrigena, on the basis of DNA-rRNA and DNA-DNA hybridization data, and of protein electrophoretic patterns and immunotyping. More detailed characterization in the current study shows that representatives of these three groups can also be differentiated phenotypically from each other. Strains of C. terrigena sensu stricto (C. terrigena DNA group 1) are pyrrolidone aminopeptidasepositive, do not grow at $40{ }^{\circ} \mathrm{C}$, are L-alanine-positive and are always negative for 4hydroxybenzoate. Strains of $C$. terrigena DNA groups 2 and 3 are pyrrolidone aminopeptidasenegative; the former is the only group that is tyrosine-negative, and only the latter can grow at $42{ }^{\circ} \mathrm{C}$ (with an optimal growth temperature of $40^{\circ} \mathrm{C}$ ). These findings are corroborated by differences in $16 S$ rDNA sequence and tRNA intergenic spacer lengths. Therefore, it is proposed to rename $C$. terrigena DNA group 2 [containing former Aquaspirillum aquaticum and E. Falsen (EF) group 10 strains] as Comamonas aquatica sp. nov., and C. terrigena DNA group 3 (containing former EF group 10 strains) as Comamonas kerstersii sp. nov.
\end{abstract}

Previously published data indicate that the species Comamonas terrigena actually comprises three genotypically separate groups. Willems et al. (1991) reported that three DNA groups could be recognized within C. terrigena; these three groups could also be recognized by immunotyping and whole-cell protein patterns, but could not be differentiated phenotypically. They were therefore not named as separate species, but maintained as genospecies within C. terrigena. Vaneechoutte et al. (1992) showed that these three DNA groups gave clearly different rDNA restriction digestion patterns, based on amplified $16 \mathrm{~S}$, spacer and the $5^{\prime}$ part of $23 \mathrm{~S}$ rDNA.

In a comparative study of SDS-PAGE whole-cell protein

The GenBank/EMBL/DDBJ accession numbers for the $16 \mathrm{~S}$ rDNA sequences reported in this paper are AJ430342-AJ430348.

Tables containing details of the strains used and $16 \mathrm{~S}$ rDNA sequence similarity values are available as supplementary data in IJSEM Online. patterns of Comamonas strains (Willems et al., 1991), Comamonas testosteroni and Comamonas acidovorans (now Delftia acidovorans) were found to have distinct and characteristic protein patterns. For 46 C. terrigena strains, including E. Falsen (EF) group 10 strains and the monotype strain of Aquaspirillum aquaticum, more variable protein patterns were observed. By numerical analysis, they were grouped into four electropherovars, $1 \mathrm{a}$ and $1 \mathrm{~b}, 2$ and 3, which correspond to $C$. terrigena DNA groups 1,2 and 3 , respectively.

In immunodiffusion analysis with antisera against one or two representative strains of each of the DNA groups of C. terrigena, three groups were again easily distinguishable. Strains reacted strongly with the antiserum of their own DNA group, and not at all, or weakly to moderately, with antisera of other groups (Willems et al., 1991).

Data obtained in the present study enable us to describe these three DNA groups as separate species. We propose to 


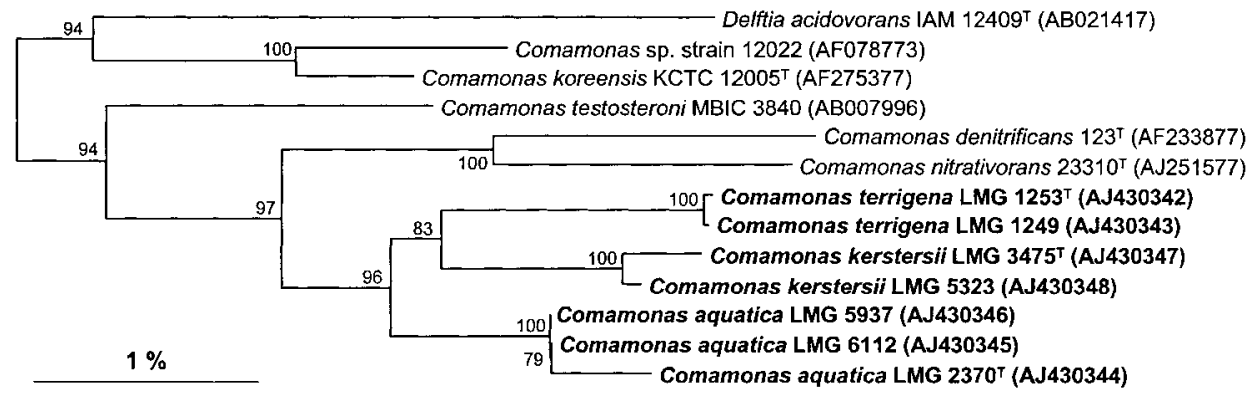

Fig. 1. Rooted $16 \mathrm{~S}$ rDNA sequence-based tree showing the relationship of the different Comamonas species. Cluster analysis, performed using GeneBase (Applied Maths), was based on the neighbour-joining method and Delftia acidovorans IAM $12409^{\top}$ was used as the outgroup. The region used corresponds to Escherichia coli positions 45-1393. Bootstrap values are shown at the branching points (proportion of 100 resamplings). Sequences in bold were obtained during this study. Bar, $1 \%$ estimated sequence divergence.

rename C. terrigena DNA group 2 as Comamonas aquatica comb. nov., and C. terrigena DNA group 3 as Comamonas kerstersii sp. nov. The strains used in this study and the characteristics tested for each strain are available as supplementary data in IJSEM Online.

Sequencing of the 16S rRNA gene and DNA similarity calculations and cluster analysis of the sequences obtained together with sequences from GenBank were carried out as described previously (Vaneechoutte et al., 2000; Nemec et al., 2001). Fig. 1 presents the $16 \mathrm{~S}$ rDNA similarity tree, with Delftia acidovorans IAM $12409^{\mathrm{T}}$ as the outgroup. The distance matrix is available as supplementary data in IJSEM Online. From these data, it is clear that the three DNA groups cluster separately and cannot be confused with C. testosteroni or the recently described species Comamonas denitrificans (Gumaelius et al., 2001), Comamonas nitrativorans (Etchebehere et al., 2001) or Comamonas koreensis (Chang et al., 2002).

Biochemical characterization was carried out according to Gilligan \& Whittier (1999); the API20NE and API ID 32 GN systems (bioMérieux) and susceptibility testing to desferrioxamine (Desferal) (Lindsay \& Riley, 1991; Laffineur et al., 2002) were also used. It was possible to differentiate the three groups from $C$. testosteroni and from each other using these methods (Table 1).

An important differential characteristic between the newly described species C. denitrificans (Gumaelius et al., 2001) and C. nitrativorans (Etchebehere et al., 2001) and the other Comamonas species is that both of the former species reduce nitrate to nitrogen. C. koreensis (Chang et al., 2002) is the only non-motile Comamonas species described so far.

All three species described in the present study are Gramnegative rods that are motile by multitrichous polar flagella, often with bipolar tufts. They are aerobic and non-fermentative, do not acidify or assimilate sugars, are urease-negative, positive for nitrate reduction and negative for nitrite reduction. They are negative for the production of indole and $\mathrm{H}_{2} \mathrm{~S}$, do not hydrolyse gelatin and produce no lysine decarboxylase, ornithine decarboxylase or arginine dihydrolase. Aesculin is not hydrolysed. Phosphatase, trypsin and acidification of ethylene glycol (Laffineur et al., 2002) give negative reactions. Citrate is not assimilated at $30{ }^{\circ} \mathrm{C}$ when tested with the ID $32 \mathrm{GN}$ system (AUX medium; bioMérieux), but assimilation-alkalinization is variable on Simmons' citrate agar.

The major cellular fatty acids of the three species are $\mathrm{C}_{16: 1}$, $\mathrm{C}_{16: 0}$ and $\mathrm{C}_{18: 1} \omega 9 c$, but $\mathrm{C}_{10: 0} 3-\mathrm{OH}, \mathrm{C}_{12: 0}$ and $\mathrm{C}_{14: 0}$ are also present, as well as small amounts of $\mathrm{C}_{15: 0}$ and $\mathrm{C}_{17: 0}$ cyclo. In contrast to C. testosteroni, $\mathrm{C}_{16: 0} 2-\mathrm{OH}$ is either not detected or is only present in trace amounts.

Table 1. Differential biochemical characteristics, as determined in this study, for C. testosteroni, C. terrigena, C. aquatica and C. kerstersii

Species: 1, C. testosteroni $(n=14) ; 2$, C. terrigena $(n=8) ; 3, C$. aquatica $(n=11) ; 4$, C. kerstersii $(n=15)$. R, Resistant; s, susceptible;,$+ 100 \%$ positive; $(+)$, positive (weak or delayed);,$- 0 \%$ positive; $\mathrm{V}$ (variable), $72 \%$ positive.

\begin{tabular}{|lccccc|}
\hline Characteristic & $\mathbf{1}$ & $\mathbf{2}$ & $\mathbf{3}$ & $\mathbf{4}$ \\
\hline Desferrioxamine & $\mathrm{R}$ & $\mathrm{S}$ & $\mathrm{S}$ & $\mathrm{S}$ \\
Testosterone utilization & + & - & - & - \\
Alkalinization on Simmons' base of glycine & + & - & - & - \\
Growth at: & & & & \\
$40{ }^{\circ} \mathrm{C}$ & - & - & $(+)$ & + \\
$42{ }^{\circ} \mathrm{C}$ & - & - & - & + \\
$44^{\circ} \mathrm{C}$ & - & - & - & + \\
Pyrrolidone aminopeptidase & + & + & - & - \\
Tyrosine hydrolysis & + & + & - & + \\
Assimilation on ID 32 GN of: & & & & & \\
3-Hydroxybenzoate & + & - & - & - \\
4-Hydroxybenzoate & + & - & $\mathrm{V}$ & + \\
L-Alanine & + & + & - & - \\
\hline
\end{tabular}


Amplification of tRNA intergenic spacers (Welsh \& McClelland, 1991) and separation of the amplified DNA fragments by capillary electrophoresis (Vaneechoutte et al., 1998; Baele et al., 2000, 2001) also makes it possible to differentiate between isolates of these three species and $C$. testosteroni and Delftia acidovorans (Table 2). A full database with all established tRNA PCR fingerprints is freely available upon request.

Given the previously published results, indicating the existence of three DNA hybridization groups within $C$. terrigena that are supported by serological and protein electrophoretic data (Willems et al., 1991), and given the clear biochemical and genotypic (16S rDNA sequence and tRNA-PCR profile) differences between the three DNA groups as established in this study, we propose that $C$. terrigena actually comprises three separate species and that C. terrigena DNA group 2 should be renamed as C. aquatica, and C. terrigena DNA group 3 as C. kerstersii.

\section{Description of Comamonas aquatica (Hylemon et al. 1973) comb. nov.}

Comamonas aquatica (a.qua'ti.ca. L. fem. adj. aquatica living in water).

Basonym: Aquaspirillum aquaticum Hylemon et al. 1973.

Table 2. Summary of the lengths of the amplified tRNA intergenic spacer DNA fragments for the different species studied

Species: 1, Delftia acidovorans $(n=8) ; 2$, C. terrigena $(n=6) ; 3$, C. aquatica $(n=3) ; 4, C$. kerstersii $(n=20) ; 5$, C. testosteroni $(n=5)$. Values are the number of isolates for which a tRNA intergenic spacer with this length was observed. Fragment lengths are means \pm SD.

\begin{tabular}{|c|c|c|c|c|c|}
\hline Fragment length (bp) & 1 & 2 & 3 & 4 & 5 \\
\hline $74 \cdot 2 \pm 0 \cdot 3$ & & & & 14 & \\
\hline $85 \cdot 5 \pm 0 \cdot 3$ & & & & 20 & \\
\hline $94 \cdot 3 \pm 0 \cdot 5$ & 7 & & & & \\
\hline $98 \cdot 2 \pm 0 \cdot 3$ & & & & 13 & \\
\hline $106 \cdot 7 \pm 0 \cdot 2$ & 8 & & & & \\
\hline $112 \cdot 1 \pm 0 \cdot 3$ & & & & & 5 \\
\hline $113 \cdot 2 \pm 0 \cdot 1$ & & & & 18 & \\
\hline $128 \cdot 6 \pm 0 \cdot 1$ & & & 3 & & \\
\hline $129 \cdot 2 \pm 0 \cdot 2$ & & & & 15 & \\
\hline $138 \cdot 7 \pm 0 \cdot 1$ & & 6 & & & \\
\hline $190 \cdot 9 \pm 1 \cdot 5$ & & & & & 5 \\
\hline $202 \cdot 9 \pm 0 \cdot 2$ & & & & & 3 \\
\hline $213 \cdot 5 \pm 0 \cdot 3$ & & & & 18 & \\
\hline $255 \cdot 4 \pm 0 \cdot 3$ & 8 & & & & \\
\hline $273 \cdot 5 \pm 0 \cdot 5$ & & & & & 5 \\
\hline $311 \cdot 7 \pm 0 \cdot 7$ & 8 & & & & \\
\hline $313 \cdot 9 \pm 0 \cdot 8$ & & & & & 3 \\
\hline $374 \cdot 8 \pm 0 \cdot 2$ & 5 & & & & \\
\hline
\end{tabular}

Gram-negative rods, motile by multitrichous polar flagella, often with bipolar tufts. Grows aerobically on tryptic soy agar and broth at 30 and $35^{\circ} \mathrm{C}$. Moderate and delayed growth in broth may be observed at $40^{\circ} \mathrm{C}$; there is no growth at $42^{\circ} \mathrm{C}$. After $24 \mathrm{~h}$ incubation at $30^{\circ} \mathrm{C}$, colonies reach a diameter of $1-1.5 \mathrm{~mm}$ on blood agar. Oxidase and catalase activities are positive. Carbohydrates are neither acidified nor assimilated. Ethylene glycol is not acidified. Urease, indole and $\mathrm{H}_{2} \mathrm{~S}$ are not produced; negative for lysine decarboxylase, ornithine decarboxylase and arginine dihydrolase. Nitrates are reduced, but nitrites are not. Tyrosine and gelatin are not hydrolysed. Simmons' citrate agar test is positive. On Simmons' minimal agar base, Lalanine and glycine are neither assimilated nor alkalinized. Using ID 32 GN strips, propionate, valerate, 3-hydroxybutyrate, L-proline, itaconate, suberate, acetate and lactate are assimilated. Utilization of caprate and 4hydroxybenzoate is variable. 3-Hydroxybenzoate and Lalanine are not utilized. Alkaline phosphatase, trypsin and pyrrolidone arylamidase are negative. Strains are susceptible to desferrioxamine and colistin. The main cellular fatty acids are $\mathrm{C}_{16: 1}, \mathrm{C}_{16: 0}, \mathrm{C}_{18: 1} \omega 9 c, \mathrm{C}_{10: 0} 3-\mathrm{OH}, \mathrm{C}_{12: 0}$ and $\mathrm{C}_{14: 0}$. The DNA G $+\mathrm{C}$ content is $62 \cdot 8-66 \cdot 7 \mathrm{~mol} \%$.

The type strain is LMG $2370^{\mathrm{T}}\left(=\right.$ CCUG $15845^{\mathrm{T}}=$ ATCC $11330^{\mathrm{T}}$ ). Its DNA $\mathrm{G}+\mathrm{C}$ content is $64 \cdot 0 \mathrm{~mol} \%$. The sequence of its 16S rDNA is available under EMBL/ GenBank accession number AJ430344.

\section{Description of Comamonas kerstersii sp. nov.}

Comamonas kerstersii (ker.ster'si.i. N.L. masc. gen. n. kerstersii of Kersters, in honour of Karel Kersters, a Belgian microbiologist, for his contribution to bacterial taxonomy).

Gram-negative rods, motile by multitrichous polar flagella, often with bipolar tufts. Grows aerobically on tryptic soy agar and broth at $30,35,42$ and $44^{\circ} \mathrm{C}$. Optimal growth occurs at $35-40{ }^{\circ} \mathrm{C}$. After $24 \mathrm{~h}$ incubation at $30^{\circ} \mathrm{C}$, colonies reach a diameter of $1.5 \mathrm{~mm}$ on blood agar, and a diameter of more than $2 \mathrm{~mm}$ may be reached at $40^{\circ} \mathrm{C}$. Oxidase and catalase activities are positive. Carbohydrates are neither acidified nor assimilated. Ethylene glycol is not acidified. Urease, indole and $\mathrm{H}_{2} \mathrm{~S}$ are not produced; negative for lysine decarboxylase, ornithine decarboxylase and arginine dihydrolase. Nitrates are reduced but nitrites are not. Simmons' citrate agar test may be positive, but irregular and delayed. Tyrosine hydrolysis is positive but gelatin hydrolysis is negative. On Simmons' minimal agar base, L-alanine and glycine are neither assimilated nor alkalinized. Using ID 32 GN strips, valerate, 3-hydroxybutyrate, L-proline, itaconate, suberate, acetate, lactate and 4-hydroxybenzoate are assimilated. Utilization of caprate is variable. L-Alanine and 3-hydroxybenzoate are negative. Alkaline phosphatase, benzylarginine arylamidase and pyrrolidone arylamidase are negative. Strains are susceptible to desferrioxamine and colistin. The main cellular fatty acids are $\mathrm{C}_{16: 1}, \mathrm{C}_{16: 0}$, $\mathrm{C}_{18: 1} \omega 9 c, \mathrm{C}_{10: 0} 3-\mathrm{OH}, \mathrm{C}_{12: 0}$ and $\mathrm{C}_{14: 0}$. DNA G $+\mathrm{C}$ content is $59 \cdot 7-63 \cdot 3 \mathrm{~mol} \%$. 
The type strain is LMG $3475^{\mathrm{T}}\left(=\right.$ CCUG $\left.15333^{\mathrm{T}}=\mathrm{AF} 61^{\mathrm{T}}\right)$. Its DNA G+C content is $61.0 \mathrm{~mol} \%$. The sequence of its $16 \mathrm{~S} \mathrm{rDNA}$ is available under EMBL/GenBank accession number AJ430347.

\section{Emended description of Comamonas terrigena sensu stricto (ex Hugh 1962) De Vos et al. 1985}

Gram-negative rods, motile by multitrichous polar flagella, often with bipolar tufts. Grows aerobically on tryptic soy agar and broth at 30 and $35^{\circ} \mathrm{C}$, but not at $40{ }^{\circ} \mathrm{C}$. After $24 \mathrm{~h}$ incubation at $30^{\circ} \mathrm{C}$, colonies reach a diameter of $1 \mathrm{~mm}$ on blood agar. Oxidase and catalase activities are positive. Carbohydrates are neither acidified nor assimilated. Ethylene glycol is not acidified. Urease, indole and $\mathrm{H}_{2} \mathrm{~S}$ are not produced; negative for lysine decarboxylase, ornithine decarboxylase and arginine dihydrolase. Nitrates are reduced but nitrites are not. Simmons' citrate agar test is positive, but may be delayed. Tyrosine hydrolysis is positive but gelatin hydrolysis is negative. On Simmons' minimal agar base, L-alanine is assimilated and alkalinized but glycine is not. Using ID 32 GN strips, propionate, valerate, 3hydroxybutyrate, L-proline, suberate, acetate, lactate and Lalanine are assimilated. Utilization of itaconate and caprate is variable. 3-Hydroxybenzoate and 4-hydroxybenzoate are always negative. Alkaline phosphatase and benzylarginine arylamidase activities are negative but pyrrolidone arylamidase is positive. Strains are susceptible to desferrioxamine and colistin. The main cellular fatty acids are $\mathrm{C}_{16: 1}, \mathrm{C}_{16: 0}$, $\mathrm{C}_{18: 1} \omega 9 c, \mathrm{C}_{10: 0} 3-\mathrm{OH}, \mathrm{C}_{12: 0}$ and $\mathrm{C}_{14: 0}$. DNA G $+\mathrm{C}$ content is $64 \cdot 0-66 \cdot 6 \mathrm{~mol} \%$.

The type strain is LMG $1253^{\mathrm{T}}\left(=\mathrm{CCUG} 15327^{\mathrm{T}}=\mathrm{NCIB}\right.$ $\left.8193^{\mathrm{T}}\right)$. Its DNA G $+\mathrm{C}$ content is $64 \cdot 0 \mathrm{~mol} \%$. The sequence of its $16 \mathrm{~S}$ rDNA is available under EMBL/GenBank accession number AJ430342.

\section{Acknowledgements}

A. W. is grateful to the Fund for Scientific Research - Flanders for a position as Postdoctoral Research Fellow. We thank Leen Van Simaey, Catharine De Ganck and Inge Bocquaert for excellent technical assistance.

\section{References}

Baele, M., Baele, P., Vaneechoutte, M., Storms, V., Butaye, P., Devriese, L. A., Verschraegen, G., Gillis, M. \& Haesebrouck, F. (2000). Application of tDNA intergenic spacer PCR for identification of Enterococcus species. J Clin Microbiol 38, 4201-4207.

Baele, M., Storms, V., Haesebrouck, F., Devriese, L. A., Gillis, M., Verschraegen, G., de Baere, T. \& Vaneechoutte, M. (2001).
Application and evaluation of the interlaboratory reproducibility of tRNA intergenic length polymorphism analysis (tDNA-PCR) for identification of Streptococcus species. J Clin Microbiol 39, 1436-1442.

Chang, Y.-H., Han, J., Chun, J., Lee, K. C., Rhee, M.-S., Kim, Y.-B. \& Bae, K. S. (2002). Comamonas koreensis sp. nov., a non-motile species from wetland in Woopo, Korea. Int J Syst Evol Microbiol 52, 377-381.

De Vos, P., Kersters, K., Falsen, E., Pot, B., Gillis, M., Segers, P. \& De Ley, J. (1985). Comamonas Davis and Park 1962 gen. nov., nom. rev. emend., and Comamonas terrigena Hugh 1962 sp. nov., nom. rev. Int J Syst Bacteriol 35, 443-453.

Etchebehere, C., Errazquin, M. I., Dabert, P., Moletta, R. \& Muxí, L. (2001). Comamonas nitrativorans sp. nov., a novel denitrifier isolated from a denitrifying reactor treating landfill leachate. Int J Syst Evol Microbiol 51, 977-983.

Gilligan, P. H. \& Whittier, S. (1999). Burkholderia, Xenotrophomonas, Ralstonia, Brevundimonas, Comamonas and Acidovorax. In Manual of Clinical Microbiology, 7th edn, pp. 526-538. Edited by P. R. Murray, E. J. Baron, M. A. Pfaller, F. C. Tenover \& R. H. Yolken. Washington, DC: American Society for Microbiology.

Gumaelius, L., Magnusson, G., Pettersson, B. \& Dalhammar, G. (2001). Comamonas denitrificans sp. nov., an efficient denitrifying bacterium isolated from activated sludge. Int J Syst Evol Microbiol 51, 999-1006.

Laffineur, K., Janssens, M., Charlier, J., Avesani, V., Wauters, G., \& Delmée, M. (2002). Biochemical and susceptibility tests useful for identification of nonfermenting gram-negative rods. J Clin Microbiol 40, 1085-1087.

Lindsay, J. A. \& Riley, T. V. (1991). Susceptibility to desferrioxamine: a new test for the identification of Staphylococcus epidermidis. J Med Microbiol 35, 45-48.

Nemec, A., De Baere, T., Tjernberg, I., Vaneechoutte, M., van der Reijden, T. J. K. \& Dijkshoorn, L. (2001). Acinetobacter ursingii sp. nov. and Acinetobacter schindleri sp. nov., isolated from human clinical specimens. Int J Syst Evol Microbiol 51, 1891-1899.

Vaneechoutte, M., Rossau, R., De Vos, P. \& 7 other authors (1992). Rapid identification of bacteria of the Comamonadaceae with amplified ribosomal DNA-restriction analysis (ARDRA). FEMS Microbiol Lett 93, 227-233.

Vaneechoutte, M., Boerlin, P., Tichy, H.-V., Bannerman, E., Jäger, B. \& Bille, J. (1998). Comparison of PCR-based DNA fingerprinting techniques for the identification of Listeria species and their use for atypical Listeria isolates. Int J Syst Bacteriol 48, 127-139.

Vaneechoutte, M., Claeys, G., Steyaert, S., De Baere, T., Peleman, R. \& Verschraegen, G. (2000). Isolation of Moraxella canis from an ulcerated metastatic lymph node. J Clin Microbiol 38, 3870-3871.

Welsh, J. \& McClelland, M. (1991). Genomic fingerprints produced by PCR with consensus tRNA gene primers. Nucleic Acids Res 19, 861-866.

Willems, A., Pot, B., Falsen, E., Vandamme, P., Gillis, M., Kersters, K. \& De Ley, J. (1991). Polyphasic taxonomic study of the emended genus Comamonas: relationship to Aquaspirillum aquaticum, E. Falsen group 10, and other clinical isolates. Int J Syst Bacteriol 41, 427-444. 